\title{
Ойратская коллекция рукописей Национального музея Тувы"
}

\author{
Баазр А. Бичеев
}

Калмыцкий научный центр Российской академии наук, Российская Федерация

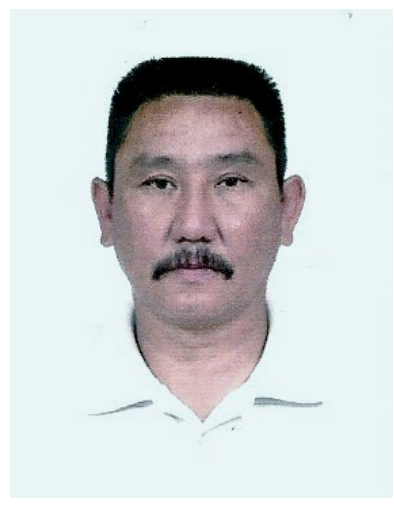

В статье дано описание небольщой, но интересной по своему содержанию коллекции ойратских текстов, хранящихся в Национальном музее им. Алдан-Маадыр Республики Тыва. В целом, здесь хранится большое собрание монгольских рукописей и ксилографов, насчитывающее 938 единиц хранения. Из них восемь текстов написаны ойратским «ясным письмом».

Наличие на территории Республики Тыва монгольских рукописей вполне объяснимо, поскольку культурно-экономические связи этого региона с Монголией были постоянными на протяжении многих веков. Интенсивность этих связей значительно возросла в период распространения и утверждения буддизма на территории современной Республики Тыва. Наличие текстов на «ясном письме» также не вызывает вопросов, поскольку оно широко бытовало у ойратов, населявших кочевья, граничащие с Тывой. Большая часть рукописей на «ясном письме», хранящаяся в монгольском фонде Института восточных рукописей РАН и Научной библиотеки им. М. Горького СПбГУ была в свое время доставлена российскими исследователями именно с этой территории.

Тувинское собрание ойратских рукописей, несмотря на небольшое количество текстов, представляет достаточно ценную коллекцию. В ней представлены как канонический текст буддизма, так и образцы популярной литературы дидактического содержания, литературные сборники, а также тексты необходимые для религиозно-обрядовой практики.

Ключевые слова: Республика Тыва; Тува; Национальный музей Тувы; каталог рукописей; ойратская коллекция; ясное письмо; литературный сборник

"Исследование проведено в рамках государственной субсидии - проект «Устное и письменное наследие монгольских народов России, Монголии и Китая: трансграничные традиции и взаимодействия» (регистрационный номер ААAA-A19-119011490036-1).

\section{Для цитирования:}

Бичеев Б. А. Ойратская коллекция рукописей Национального музея Тувы [Электронный ресурс] // Новые исследования Тувы. 2019, № 4. URL: https://nit.tuva.asia/nit/article/view/878 (дата обращения: дд.мм.гг.). DOI: 10.25178/ nit.2019.4.2

Бичеев Баазр Александрович - доктор философских наук, ведущий научный сотрудник отдела монгольской филологии Калмыцкого научного центра Российской академии наук. Адрес: 358000, Россия, г. Элиста, ул. И. К. Илишкина, д. 8. Тел.: +7 (84722) 3-55-06. Эл. адрес: baazr@mail.ru ORCID ID: 0000-0002-9352-7367

Bicheev Baazr Alexsandrovich, Doctor of Philosophy, Leading Research Associate, Department of Mongolian Philology, Kalmyk Scientific Center, Russian Academy of Sciences. Postal address: 8 Ilishkin St., Elista 358000 Russian Federation. Tel.: +7 (84722) 3-55-06. Email: baazr@mail.ru 


\title{
An Oirat literary collection from the National Museum of Tuva
}

\author{
Baazr A. Bicheev \\ Kalmyk Scientific Center of the Russian Academy of Sciences, Russian Federation
}

\begin{abstract}
The article aims to describe a small but essentially interesting collection of Oirat-language texts contained in the AldanMaadyr National Museum of the Tyva Republic. The museum houses quite a number of Mongolian manuscripts and woodblock prints numbering 938, including eight ones written in Oirat Clear Script.

The presence of Mongolian manuscripts in Tuva can well be explained by close centuries-old cultural and economic ties between the region and Mongolia. The intensity of the ties increased significantly during the dissemination and consolidation of Buddhism in the territory of the present-day Tyva Republic. As for the Clear Script texts, those might have been borrowed from Oirat nomadic populations that inhabited Tuva's border areas. The bulk of Clear Script manuscripts contained in respective departments of the Institute of Oriental Manuscripts (RAS) and the Gorky Scientific Library (Oriental Studies) of St. Petersburg State University were delivered by Russian researchers from exactly this territory.

Though not that extensive, the Tuvan collection of Oirat manuscripts is of significant value, since it includes both canonical texts of Buddhism and somewhat popular didactic compositions, as well as texts dealing with lay religious-and-ceremonial practices.
\end{abstract}

Keywords: Tuva Republic, Tuva, National Museum of Tuva, catalogue of manuscripts; Oirat collection; Clear Script; literary collection

"The reported study was funded by government subsidy - project name 'Oral and Written Heritage of the Mongolic Peoples of Russia, Mongolia and China: Cross-Border Traditions and Interactions' (registration number AAAA-A19-119011490036-1).

\section{For citation:}

Bicheev B. A. An Oirat literary collection from the National Museum of Tuva. The New Research of Tuva. 2019, no. 4 [online] Available at: https://nit.tuva.asia/nit/article/view/878 (access date ... ). DOI: 10.25178/nit.2019.4.2

\section{Введение}

Старописьменная ойратская литература насчитывает без малого четыре века своей истории. Создание в 1648 г. ойратского алфавита, известного как «ясное письмо», и последовавшая вслед за этим активная переводческая деятельность послужили началом ее зарождения. Письменная традиция как показатель потенциала этнической культуры, способной ответить на духовные потребности общества, является одним из важных факторов самоидентификации этноса. Значимость такой культурной традиции наиболее зримо проявляется в ситуации социальной катастрофы, когда этнос, оказавшись на грани выживания, стремится сохранить не только себя, но и свое культурное достояние.

В катастрофической ситуации, когда этносу приходится сталкиваться, по сути, с вопросом своего существования, ойраты оказывалось неоднократно. В середине XVIII в. таким трагическим событием стало падение Джунгарского ханства (1758 г.), когда в результате маньчжуро-китайско-монгольской экспансии геноциду подверглось около миллиона ойратов. Их храмы и крепости были разрушены, а письменное наследие бесследно уничтожено. Во второй половине того же XVIII в. в такой же катастрофической ситуации оказалась калмыки Российской империи. Во время исхода основной массы калмыков с берегов Волги на историческую родину в 1771 г. погибло их большая часть. Окончательный урон культурному наследию оставшейся части ойратского этноса в России и Китае был нанесен в результате депортации калмыков в Сибирь (1943-1956 гг.) и культурной революции в Китае (1966-1976 гг.).

Тем не менее, в научных фондах, монастырских библиотеках и частных коллекциях России, Монголии и Китая все же сохранились тексты на «ясном письме». Эти немногочисленные рукописи и ксилографы свидетельствуют не только о самобытности ойратской старописьменной литературы, 
но и о том интересе, которые проявляли к ней соседствующие с ними народы. Подтверждением этому служит и тувинская коллекция ойратских рукописей, часть из которых уже введена в научный оборот в текущем году (Бембеев, Бичеев, Бичелдей, 2019: Электр. ресурс; Манджиева, Сумба, 2019: Электр. ресурс; Мирзаева, 2019: Электр. ресурс).

В данной статье дается общий анализ всех восьми рукописей тувинской коллекции, позволяющий представить ее как единое собрание текстов, отражающее разные уровни религиозной практики в период распространения буддизма на территории Тувы.

\section{Тувинская коллекциия ойратских рукописей}

Самое крупное собрание текстов на «ясном письме» сохранилось в Монголии. Более одной тысячи рукописей находятся в фонде Института языка и литературы Монголии (Gerelmaa, 2005), свыше 300 текстов хранятся в Музее Увс аймака, еще 336 текстов в Национальной библиотеке Монголии (Тунгалаг, 2006). Небольшая коллекция из 70 рукописей сохранилась в Доме-музее академика Ц. Дамдинсурэна (Билгүүдэй, Отгоонбаатар, Цендина, 2018). К сожалению, не учтенными остаются тексты, хранящиеся в рукописном фонде Ховдского университета, частных коллекциях и монастырских библиотеках Западной Монголии.

Большая часть ойратских рукописей в Синьцзян-Уйгурском автономном районе КНР была уничтожена в годы культурной революции. Все, что удалось сохранить и собрать за последние четыре десятилетия хранится в г. Урумчи в Кабинете по сбору, каталогизации и изданию письменного наследия национальных меньшинств Управления по делам национальностей СУАР КНР. По данным рабочего каталога, составленного хранителем фонда До. Галданом, в нем насчитывается 345 рукописей. Однако за последнее время на территории Или-Казахской автономной провинции, где проживают более тридцати тысяч ойратов (олетов), выявлено более двухсот личных коллекций. По приблизительным данным, в них находится свыше тысячу текстов на «ясном письме». Факсимиле более 100 обнаруженных им текстов опубликованы профессором Центрального университета национальностей М. Эрдэмтом в 26 томах серии «Собрание рукописей на «ясном письме», хранящихся в Илийском округе» (Erdemtu, 2015).

Наиболее крупные собрания ойратских рукописей и ксилографов в России находятся в СанктПетербурге. Из 505 экземпляров состоит ойратская коллекция Института восточных рукописей РАН (Сазыкин, 1988; Яхонтова, 2014) и свыше 300 текстов хранятся в Научной библиотеке им. М. Горького по направлению востоковедение Санкт-Петербургского государственного университета (Uspensky, 1999).

Небольшие коллекции ойратских текстов имеются в рукописных фондах Калмыцкого научного центра РАН ${ }^{1}$ (г. Элиста) и Института монголоведения, буддологии и тибетологии СО РАН (г. Улан-Удэ).

О том, что в фондах Национального музея им. Алдан-Маадыр Республики Тыва (далее - HМ РТ) хранится большая коллекция монгольских рукописей и ксилографов, насчитывающая более 900 единиц хранения, стало известно после публикации известного российского монголоведа А. Г. Сазыкина (1943-2005). Описывая эту коллекцию, он отмечал, что по состоянию на 1985 г. она насчитывала 938 единиц хранения, из которых восемь рукописей представляли тексты, написанные ойратским «ясным письмом» (Сазыкин, 1992: 45).

Основную часть монгольской коллекции, по словам А. Г. Сазыкина, составили материалы, «поступившие из существовавших прежде на территории Тувы буддийских монастырей. Попало в фонды музея и несколько домашних библиотек, как правило, довольно скромных по объему и содержащих преимущественно рукописи, относящиеся к религиозной обрядовой практике ламаистов, а также к повседневной бытовой их деятельности. Некоторые рукописи были подарены или проданы музею частными лицами» (там же: 49-50).

Наличие в Туве монгольских рукописей не вызывает вопросов, поскольку постоянные культурноэкономические связи этого региона с Монголией общеизвестны. Интенсивность этих связей значительно возросла в период распространения и утверждения буддизма среди тувинцев. Г.Е. ГрумГржимайло в своей работе «Западная Монголия и Урянхайский край» пишет, «Ламайских монастырей в Урянхайской земле сравнительно немного. Старейший из них, известный своей весьма богатой библиотекой тибетских книг, Соён куре (кяря, хурэ) находится на левом берегу реки Тес» (Грум-Гржимайло, 1926: 150).

${ }^{1}$ См.: Орлова, 2002; Музраева, 2012. В КалмНЦ РАН активно проводятся исследования отдельных памятников и сборников рукописей (см., например, из недавних работ: Бичеев, 2019; Мирзаева, Тувшинтугс, 2019 и др.). 
Косвенным подтверждением происходившего в прошлом процесса распространения буддизма среди тувинцев служит и тот факт, что из 84 молитвенных текстов монгольской коллекции рукописей половину составляют тексты буддийской молитвы «Прибежище» («Itegel»). Текст молитвы Прибежища квинтэссенция учения Будды. Он был широко распространен и имелся в семье каждого верующего. Его предписывалось читать трижды в светлое и трижды в темное время суток.

Поскольку большая часть рукописного фонда музея была сформирована из источников, поступивших из буддийских монастырей, расположенных на территории Тывы, следует предположить, что наличие этих текстов было необходимо тувинцам как для усвоения философских догматов буддизма, так и для повседневной религиозно-обрядовой практики. Наличие текстов на «ясном письме» также объяснимо, поскольку оно широко бытовало у ойратов, населявших кочевья, граничащие с Тувой. Скорее удивляет столь малое количества текстов на «ясном письме», которым активно пользовались ойраты Западной Монголии. Именно оттуда в свое время была доставлена отечественными монголоведами основная часть рукописей на «ясном письме», хранящаяся сегодня в фондах Института восточных рукописей РАН и в Научной библиотеке им. М. Горького по направлению востоковедение СПбГУ (Сазыкин, 1988: 14).

Несмотря на небольшое количество, тексты на «ясном письме» являются оригинальным собранием в составе монгольских рукописей и печатных книг НM РТ. Ойратские тексты, представленные в тувинской коллекции, хорошо знакомы исследователям. Но, как известно, двух одинаковых рукописей одного текста не существует. Каждая из них в той или иной степени отличается от другой какими-то своими особенностями. Поэтому с одной стороны, эти тексты свидетельствуют о популярности тех или иных произведений буддийской литературы в широкой среде верующих Тувы, а с другой - отражают особенности языка ойратов Западной Монголии.

\section{Буддийский канонический текст}

Канонический текст представлен в ойратской коллекции НМ РТ одним сочинением, хранящимся под шифром М-776 «Священная сутра Махаяны под названием “Приумножение [основ] благоденствия” («Xutuqtu ölzöi dabxurlaqsan kemēkü yeke külgüni sudur oršibo»).

Согласно содержанию колофона, текст был переведен с тибетского на ойратский язык Зая-пандитой Намкайджамцо (1599-1662) по просьбе Ахали Алдара, который был одним из влиятельных представителей ойратской знати середины XVII в. Известно, что особо почитаемая в буддийском мире «Сутра Золотого света» («Altan gerel»), также была переведена Зая-пандитой по его просьбе (Лувсанбалдан, 1975: 125-131).

Эту усмиряющую вредоносные влияния на всех существ,

Чистую сутру, способствующую накоплению [основ] благополучия,

По просьбе преисполненного благоговением Ахали Алдара,

Ради обретения десяти парамит Арья Будды,

Перевел монах Огторгуйн Далай Рабджам Зая-[пандита] (перевод наш. - Б. Б.).

amitan bügüde-yin ada todxori amurliulun:

ariun ölzöi xutuq dabxur bütēqči ene suduri:

ārya burxani arban barami=di olxuyin tula

angkidaxui ügei süzüq-tü Axali Aldar duraduqsan-du:

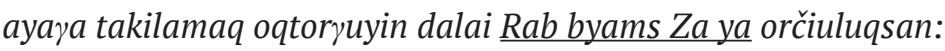

[M-776, л. 8b].

В сутре «Приумножение [основ] благоденствия» в традиционной форме диалога между Буддой и одним из его учеников (в данном случае Манджушри) в сконцентрированном виде раскрываются концептуальные основы буддийского учения и практическая польза от чтения этой сутры. Особенность этого текста заключается в том, что в кругу окружения, которому Будда обычно даровал наставления, на этот раз оказываются будды и бодхисатвы, олицетворяющие восемь символов ума. Восьмеричный путь порождает два вида особого состояния сознания - побуждающую бодхичитту и воздействующую бодхичитту. Такой аспект ума способствует практике шести парамит. Следовательно, появление этого текста в Туве было связано с необходимостью усвоения, как философских основ буддизма, так и с чисто практической точки зрения. 


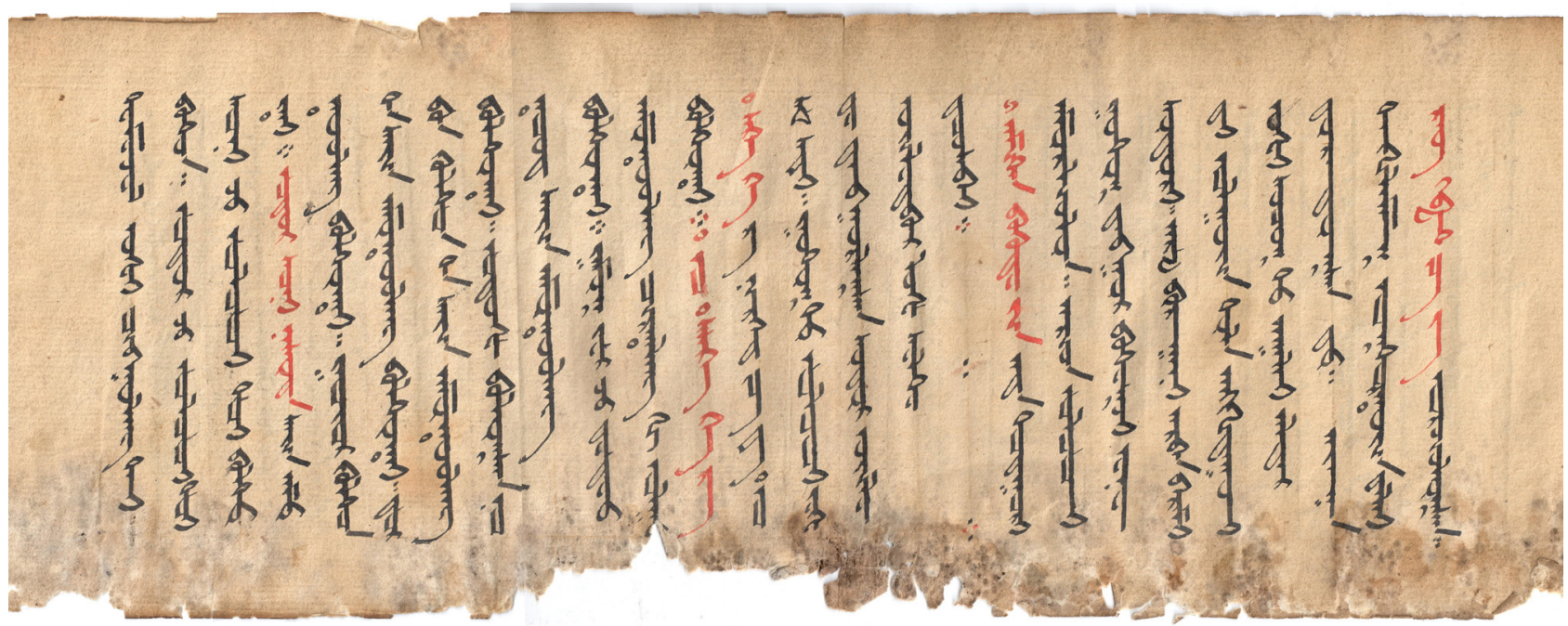

Фото 1. Лист 8b рукописи M-776 «Xиtuqtu ölzöi dabxurlaqsan kemēkü yeke külgüni sudur oršibo».

Из фонда Национального музея им. Алдан-Маадыр Республики Тыва.

Photo 1. Page $8 b$ of the manuscript M-776 «Xutuqtu ölzöi dabxurlaqsan kemēkü yeke külgüni sudur oršibo».

From the collections of the Aldan-Maadyr National Museum of the Republic of Tuva.

По всей видимости, значимость этого текста действительно была велика для верующих Тувы, поскольку в годы гонения на религию она была спрятана в природном тайнике (в пещере или под камнями). Об этом свидетельствует внешний вид рукописи. Один край листов рукописи подвергся воздействию влаги и истлел. По всему краю видны следы высохшей плесени. Однако сам текст не пострадал. На листах рукописи имеются потеки, разрывы и фоксинги. О другом подобном случае, связанном с монгольским текстом под названием «Комментарии о пользе “Ваджраччхедики” (М-275), который также был найден в пещере и передан в дар НM РТ, упоминает в своей статье А. Г. Сазыкин (Сазыкин, 1992: 50).

Сутра «Приумножение [основ] благоденствия» представляет собой образец ойратской рукописной книги традиционного оформления. Текст написан четким почерком на 9 листах плотной бумаги желтого цвета. На лицевой стороне титульного листа название сочинения заключено в двойную рамку красного цвета. На обороте титульного листа пространство разделено на пять частей двойной рамкой красного цвета. В большей по размеру центральной части листа написаны начальные строки текста.

При письме использована тушь черного и красного цветов. Красным цветом выделены слова четвертой строки с начала, четвертой строки с конца текста, а также в центральной части каждого листа. С одной стороны выделение слов мантр, имен будд придавало тексту некоторую торжественность, с другой - придавало рукописной книге визуальную привлекательность, а также имело чисто практическое назначение, разбивка текста на три части способствовала более легкому чтению.

\section{Сборник мантр пяти защитниц}

В среде простых верующих особым почтением пользовалась Бодхисаттва Тара и ее различные спокойные и гневные формы воплощений. Существуют разные тексты, посвященные культу Тары (Зорин, 2009; Бичеев, 2013). Одним из них является собрание пяти сутр «Панчаракша» (санскр. paňcarakșā; тиб.

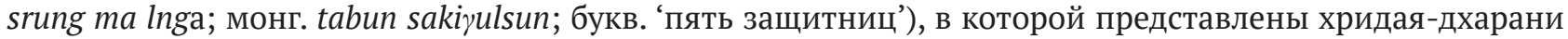
(ойp. zürken tarni) пяти эманаций Тары: Махапратисара (ойр. Хutuqtu öbör daxaqči eke; букв. ‘Великая разделяющая мать'ㄱ), Махасахасрапрамардани (ойр. Xutuqtu yeke mingrani daduqči eke; букв. 'Великая мать тысячекратная уничтожительница'), Махамаюри (ойр. Xutuqtu toyošiyin zürtani; букв. 'Великая мать в образе павлина'), Махашитавати (ойр. Xutuqtu seriün oi kemēkü eke; букв. 'Великая мать прохладная

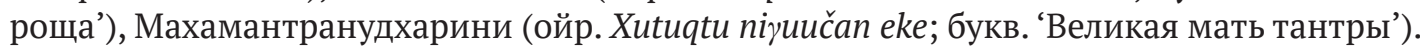

'B ойратском тексте она названа Xutuqtu öbör daxaqči eke; букв. - ‘Великая мать, следующая за каждым’. 
Конечно же, дхарани пяти защитниц, как и сакральные мантры других будд и бодхисаттв буддийского пантеона, читались простыми верующими не ради постижения тайных тантрических практик, а для совершения ритуала, обеспечивающего защиту от потери здоровья, негативных воздействий и других угроз. Видимо, такое же практическое назначение имел небольшой сборник из ойратской коллекции НМ РТ под шифром М-835 «Ekeyin zürken tarni orošiboi» («Хридая-дхарани матери [Тары]»), который состоит из нескольких текстов дхарани.

Анализ содержания текста показывает, что он состоит из сакральных формул хридая-дхарани пяти защитниц, «Дхарани тринадцати чакр, отвращающей влияние духов си» и знаменитой буддийской мантры Ваджрасаттвы (санскр. vajra-sattva, тиб. rdo ře sempa, ойр. bādzar sadv) известной как мантра ста слогов (тиб. yig brgya).

Дхарани пяти защитниц, тринадцати чакр и мантра Ваджрасаттвы связаны с тантрическим буддизмом. Дхарани тринадцати чакр, мантре ста слогов, как и дхарани пяти защитниц, приписываются те же функции - защита от многих заболеваний, избавление от негативных качеств ума (злость, зависть, ненависть). Считается, что эти мантры служит для подготовки сознания к более сложным медитативным техникам.

Рукопись, видимо, представляла собой либо сшитую тетрадь малого формата, либо складную книгу (гармонику), написанную на плотной бумаге желтого цвета, которая в случае необходимости всегда находилась при себе. Само состояние рукописи свидетельствует о ее частом использовании. Бумага износилась по линии сгиба, и единый лист книги (если это была гармоника) или сшитые листы тетради распались на отдельные листы, часть из которых утеряна. Сохранилось лишь 8 листов небольшого размера $(7 \times 9$ см). Края листов сильно истрепаны, имеются разрывы и фоксинги на большей части рукописи.

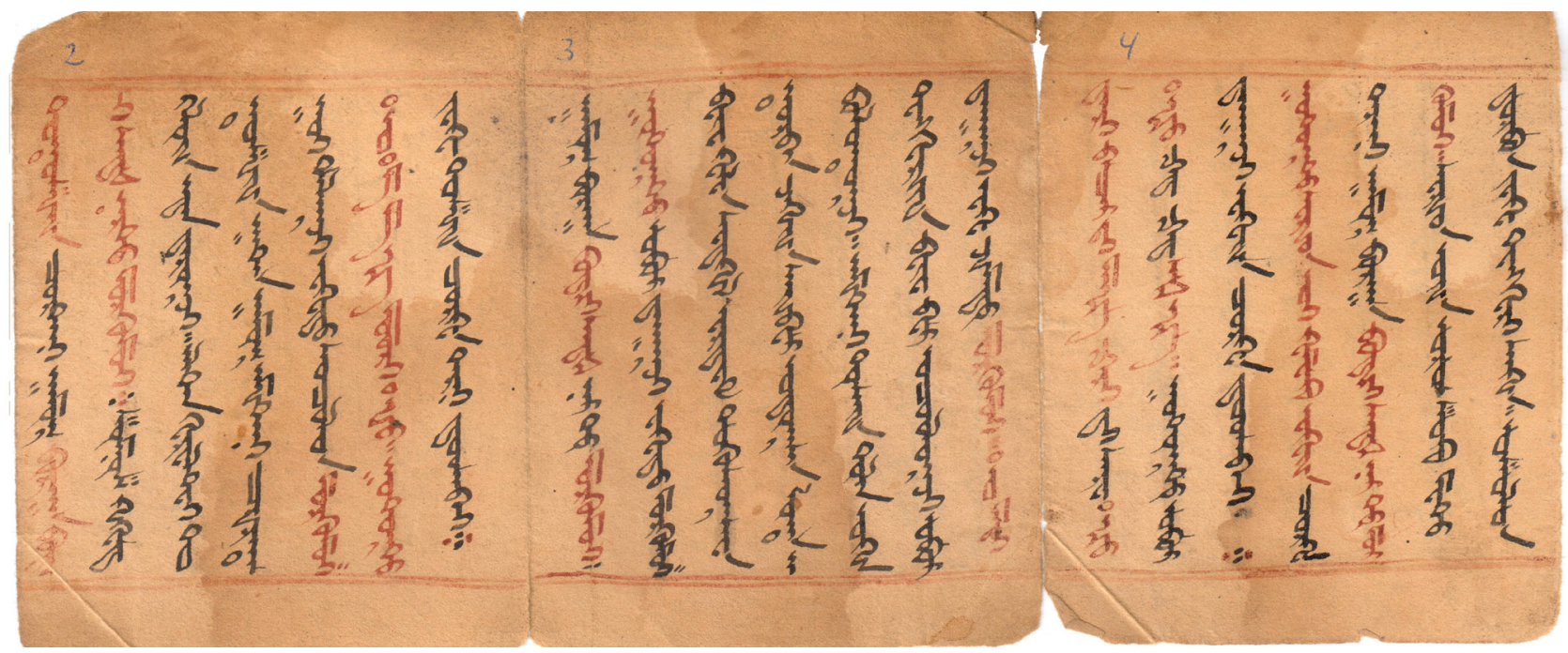

Фото 2. Листы рукописи М-835 «Ekeyin zürken tarni orošiboi». Из фонда Национального музея им. Алдан-Маадыр Республики Тыва.

Photo 2. Pages of the manuscript M-835 «Ekeyin zürken tarni orošiboi».

From the collections of the Aldan-Maadyr National Museum of the Republic of Tuva.

K сожалению, состояние рукописи и отсутствие пагинации на листах усложняет определение точой последовательности входящих в нее текстов. Но поскольку на титульном листе в красной тройной рамке красного цвета написано название «Ekeyin zürken tarni orošiboi» («Хридая-дхарани матери [Тары]»), то можно предположить, что мантра Ваджрасаттвы следовала за текстом «Панчаракши» и располагалась в конце рукописной книги. Текст мантры ста слогов, в отличие от дхарани пяти защитниц написан четким крупным почерком.

Оба текста представляют интерес не только как образцы рукописных книг малого формата с текстами дхарани, но и как тексты, в которых наглядно можно увидеть использование транскрипционных знаков (галиков) «ясного письма» для обозначения и передачи санскритских знаков. 


\section{Дидактические сочинения}

Две рукописи ойратской коллекции НМ РТ представляют собой тексты дидактического содержания. Один из них известный в монгольском мире сборник поучений или наставлений под шифром М-658 «Ключ разума» («Oуouni tülkü̈̈r kemēkü sudūr orošiboi»), приписываемых самому Чингис-хану (Сазыкин, 1992: 45; Яхонтова, 1992, 2001). Текст этого наставления имел широкое хождение на «ясном письме», о чем свидетельствует не только упомянутая рукопись, но также и тринадцать других списков этого сочинения, хранящихся в России, Монголии и Китае (Сазыкин 1988: № 80; Uspensky, 1999: № 936 (6); Gerelmaa, 2005: № 965-971; Тунгалаг, 2006: № 311- 312).

Содержание сочинения состоит из двух частей. Первая часть включает поучения, приписываемые Чингис-хану, вторая - заимствованные нравоучительные сюжеты из известного в буддийском мире сборника наставлений «Субхашиты». В списке рукописи М-658 из НМ РТ полностью сохранилась лишь первая часть произведения. Листы с меньшей по объему второй частью сочинения утеряны. Рукопись написана четким почерком. Края листов сильно изношены. Имеются заломы и разрывы на всех листах рукописи. Определенные слова или выражения на некоторых листах выделены красным цветом.

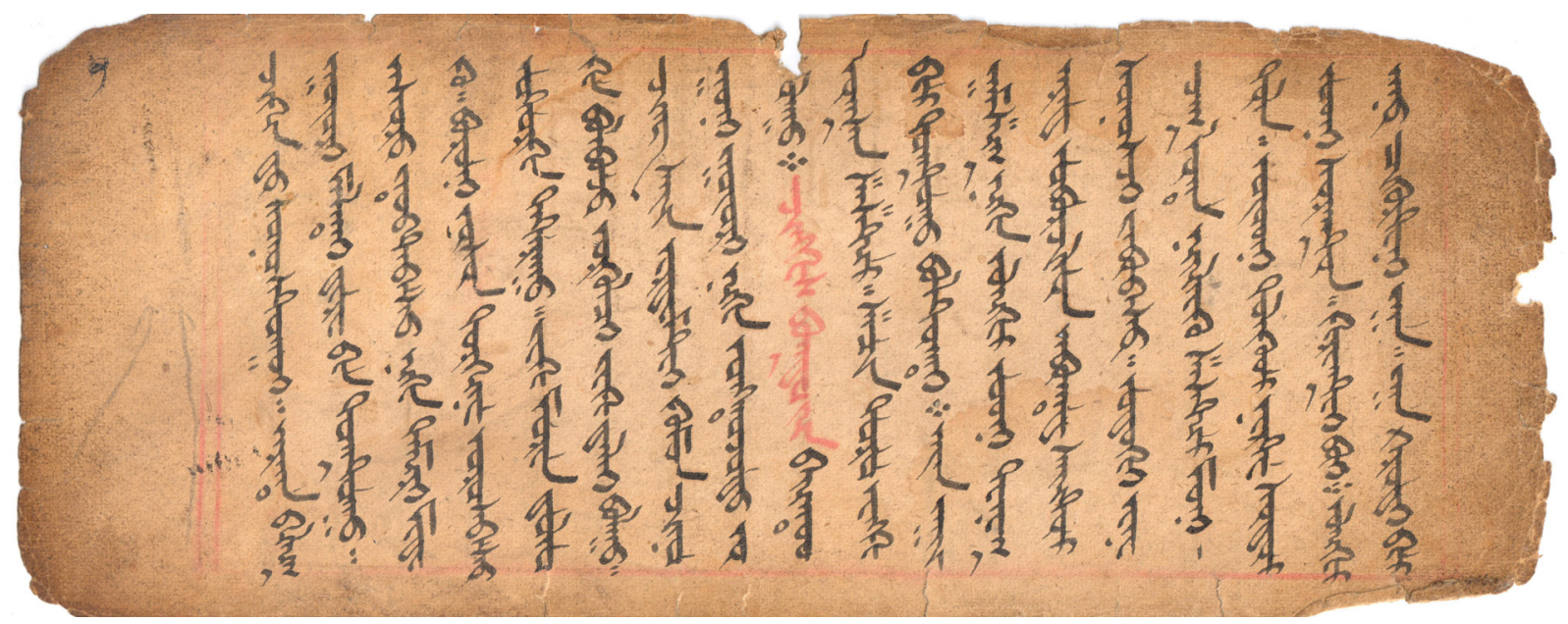

Фото 3. Лист 11 рукописи M-658 «Oуоuni tülküür kemēkü sudūr orošiboi».

Из фонда Национального музея им. Алдан-Маадыр Республики Тыва.

Photo 3. Page 11 b of the manuscript M-658 «Oyouni tülküür kemēkü sudūr orošiboi».

From the collections of the Aldan-Maadyr National Museum of the Republic of Tuva.

Второй текст дидактического содержания - «Шастра под названием “Золотые четки” (М-280 «Getülgeqči Pa-dambayin zokoqsan zurugiyin ${ }^{1}$ altan erikin kemekü šašatir orošiboi»). В монгольском собрании HM РТ также находятся два текста под близким ойратскому списку названием "Boyda Pa-damba blam-ayin jokiya $\gamma$ san altan erike neretii šastir orošiba" (M-152, M-877).

А.Г.Сазыкин называет автором этого сочинения знаменитого индийского наставника Падма Самбхаву (VIII в.), известного в Тибете также как Гуру-ринпоче. Хотя в других монгольских переводах

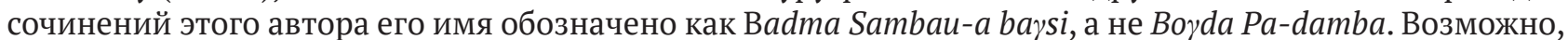
что Pa-damba (ум. 1117) - это другой великий индийский наставник Падампа Сангье (тиб. pha dam pa sangs rgyas), или Дампа Сангье (тиб. dam pa sangs rgyas), который в Тибете распространил учение Шичже (тиб. zhi byed; букв. 'Умиротворение страданий'). В этом случае автором указанного выше сочинения является Падампа Сангье, а не Падма Самбхава.

По мнению А. Г. Сазыкина, текст представляет собой «поучение, написанное в форме шастры» (Сазыкин, 1992: 53-54). Однако «Шастру под названием “Золотые четки”», судя по ее содержанию, скорее следует причислить к текстам наказов-пророчеств, рукописные списки которых имели широкое хождение в монгольском мире (Меняев, 2016).

Текст написан в форме диалога между Падампа Сангье (Pa-damba) и Анандой (Ānada), который вместе с братом Аннурудхой (Andi) пришел навестить учителя, медитировавшего в горах на границе

${ }^{1}$ В конце рукописи название дано как «Getülgeqči Pa-dambayin zokoqsan zorigiyin altan erikin kemekü šašatir dourisabai». Видимо, переписчик допустил ошибку или написал это слово так, как было написано в рукописи, с которой делалась копия. 
между Тибетом и Непалом. Увидев его плачущим, Ананда спрашивает его о причине его печали. Учитель, поведав о том, что вскоре учение Будды придет в упадок, объясняет причины, по которым это может произойти.

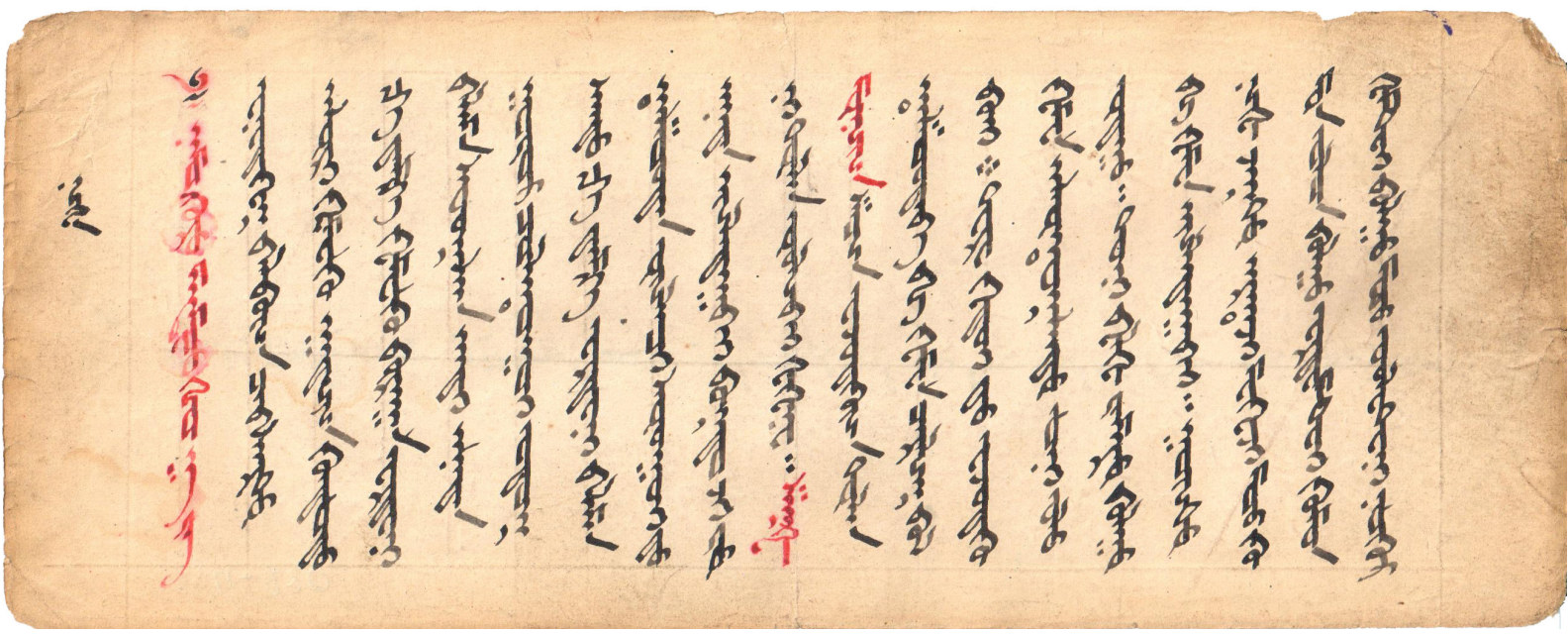

Фото 4. Лист 1 рукописи M-280 « Getülgeq̌̌i Pa-dambayin zokoqsan zurugiyin altan erikin kemekü šašatir orošiboi». Из фонда Национального музея им. Алдан-Маадыр Республики Тыва.

Photo 4. Page $1 b$ of the manuscript M-280 « Getülgeqči Pa-dambayin zokoqsan zurugiyin altan erikin kemekü šašatir orošiboi».

From the collections of the Aldan-Maadyr National Museum of the Republic of Tuva.

Произведение представляет собой обычную форму проповеди, в которой пророчества выступают как результат тех деяний, что могут произойти в случае победы зла и греховности над добром и благом. В тексте самого памятника предсказания носят общий характер, как то: упадок нравственности приведет к тому, что дети не будут почитать родителей; монахи перестанут почитать учителей-наставников; сильный будет угнетать слабого; будет война, брожение умов и т. д.

Соответственно спасением от такой неблагой участи может стать только твердое следование по пути, проповеданному Буддой.

\section{Литературные сборники}

В старописьменной ойратской литературе известны сборники, которые составлялись из наиболее известных и широко распространённых произведений. Иногда они имели смешанный характер, когда литературные сочинения могли соседствовать с фольклорными, обрядовыми и астрологическими текстами. Образцы таких сборников имеются в ойратской коллекции Института восточных рукописей РАН (Сазыкин, 1988: № 425, № 2170, № 2171, № 2178) и Научной библиотеки им. М. Горького по направлению востоковедение СПбГУ (Uspensky, 1999: № 428).

Об одном из таких сборников упоминает известный калмыцкий ученый Н. Очиров. Среди 26 рукописей, собранных им для библиотеки Санкт-Петербургского университета во время его поездок по улусам Астраханских калмыков в 1911 гг., указан один литературный сборник. Он состоял из трех произведений - «История Усун Дебескерту-хана» («Үсн Девскрт хаана тууж»), «Повесть о Будде и брахмане» («Бурхн багш бирмн хойр») и «Манджушри нама сангити» («Өгүлгч Келнә эркт Қөөлн эгшгт») (Очиров, 1913: 90).

В числе восьми рукописей, написанных ойратским «ясным письмом» и хранящихся в НМ РТ, находятся два литературный сборника. Один из них состоит из двух небольших по своему объему, но широко известных в старописьменной ойратской литературе произведений - «Повесть о Будде брахмане» («Бурхн багш бирмн хойр») и «Повесть о трехлетнем мальчике» («Гurban nasutu kü̈̈keni touji orošiboi»). Большинство ойратских рукописей в собрании НМ РТ довольно позднего происхождения - не ранее начала XIX в. и лишь одна из них, озаглавленная «Blaman yurban baqši birman rurban nasutu küüken», по мнению А. Г. Сазыкина, может быть отнесена к XVIII столетию (Сазыкин, 1992: 45). 
На титульном листе этого небольшого по объему сборника под шифром M-834 указано его название «Blamayin yurban baqši birman yurban nasutu kü̈̈keni». Обычно ойратские рукописные сборники не имеют общего названия, либо на титульном листе указывается название первого произведения. В данном случае составитель (или переписчик) попытался в этом общем названии указать маргинальное название двух произведений. Один текст «Повесть о трехлетнем мальчике» («Гurban nasutu küükeni touji orošiboi») в названии сборника определяется достаточно легко - «үurban nasutu kü̈̈keni». А вот с названием другого текста «Повесть о Будде брахмане» («Бурхн багш бирмн хойр») у переписчика получилась некоторая путаница. Дело в том, что это произведение известно под несколькими названиями - «Повесть о Будде и брахмане» («Burxan baqši birman хоуоrin tuиji»), «Повесть об умном брахмане» («Uxāta birmani touǰi»), «Повесть о гневном брахмане» («Doqšin birman-ni tuuji»). Есть рукописи, название которых составлено по первым словам начальной строки произведения, например: «Учителю-наставнику неразличимого с Буддой...» («Blama luүā ilyal ügei Burxan baqšiyin»).

По всей видимости, название первого произведения - «Blamayin yurban baqši birman» (букв. Учителю-наставнику, Трем... Будда и брахман) - это результат ошибки переписчика.

Следует также отметить, что «Повесть о Будде и брахмане» неизвестна в старомонгольской графике. Поэтому исследователи, которые не были знакомы с этой повестью на «ясном письме» как с отдельным произведением, воспринимали его не как сборник из двух текстов, а как одно произведение. Оба текста построены в форме диалога и принадлежат к одному виду произведений, которые принято обозначать как наставления, поучения (сургаал). Если в первом произведении действующими лицами выступают Будда (в образе простого монаха) и брахман, то во втором - китайский учитель Гууши и трехлетний мальчик. Тем не менее, исследователи пишут, что в этом произведении (имея в виду «Повесть о трехлетнем мальчике») Будда, приняв облик трехлетнего мальчика, усмирил высокомерного брахмана (Тойм, 1976: 200). В действительности же оба произведения, включенные в литературный сборник, существовали как два самостоятельных произведения.

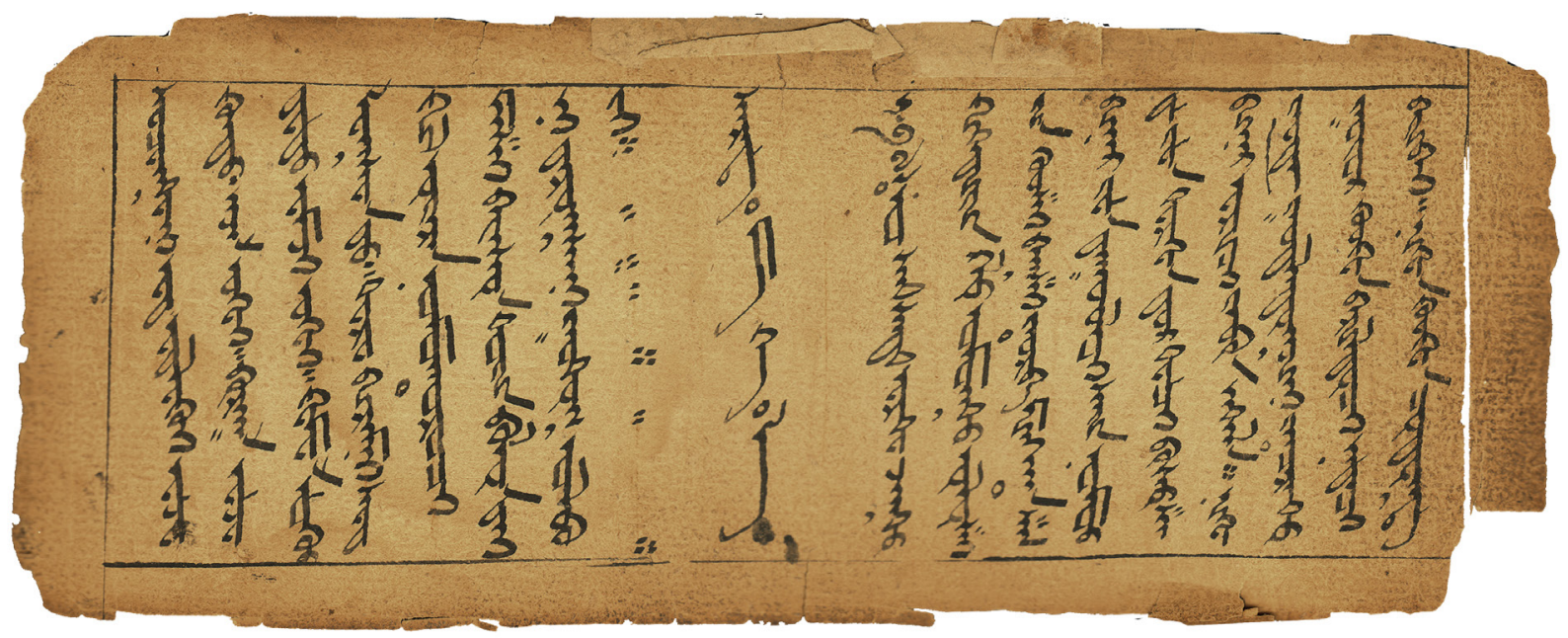

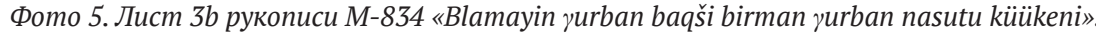

Из фонда Национального музея им. Алдан-Маадыр Республики Тыва.

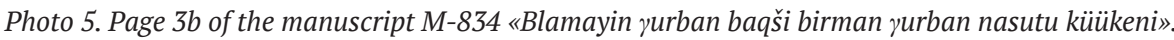

From the collections of the Aldan-Maadyr National Museum of the Republic of Tuva.

Два произведения, из которых составлен ойратский сборник из фондов НМ РТ, являются интересными образцами литературы народного буддизма. С одной стороны они близки по своей форме, но с другой - отличаются своим содержанием. В первой повести через диалог Будды и брахмана раскрывается суть буддийского закона о причинно-следственной связи всех явлений сансары. Согласно этому закону причиной всех страданий человека в этом мире являются три аффекта - невежество, гнев и вожделение. За добрые деяния следует награда, за пороки - наказание. Кто не совершает греховных деяний, тот не накапливает негативной кармы. Отсутствие таковой помогает избавиться от падения в три низшие формы рождения. От страданий можно освободиться только собственными усилиями, рассеяв невежество, усмирив гнев и преодолев привязанность к чувственному миру.

В содержании второй повести мы не найдем буддийских установок. Здесь через диалог Учителя Гууши и трехлетнего мальчика раскрывается традиционная мировоззренческая концепция кочевого 
монгольского мира - арга билик (метод и мудрость). Арга билиг - это объяснение внутренней сущности вселенной, природы, взаимоотношения человека и природы. В его основе лежит понимание того, что гармония в мире определяется единством и борьбой противоположных начал. Вне этого закона мир существовать не может.

Второй сборник под шифром M-572 «Maniyin tayilbuur orošibo» также состоит из двух произведений, т. е. минимального количества, которое позволяет квалифицировать текст как литературный сборник. Он назван по первому произведению - «Maniyin tayilbuur orošibo». В этом первом произведении даются разъяснения к скрытому содержанию известной во всем буддийском мире мантры Бодхисаттвы Авалокитешвары - «Ом мани падме хум». Обычно ее называют мантрой шести слогов или кратко по второму и третьему слогам - «мани».

Текст этого первого произведения сборника заканчивается на лицевой (recto) стороне листа 8а.

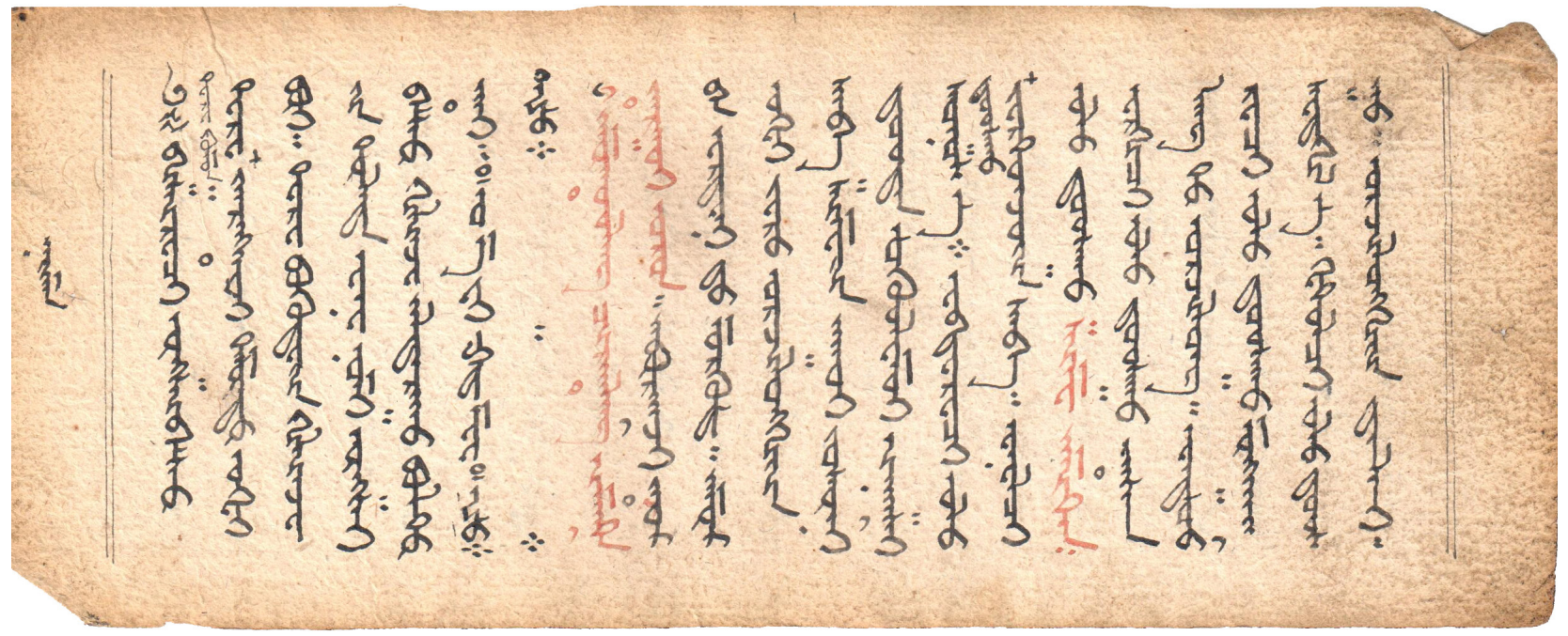

Фото 6. Лист 8а рукописи М-572 «Maniyin tayilbuur orošibo». Из фонда Национального музея им. Алдан-Маадыр Республики Тыва.

Photo 6. Page 8 a of the manuscript M-572 «Maniyin tayilbuur orošibo». From the collections of the Aldan-Maadyr National Museum of the Republic of Tuva.

Вторую часть сборника составляет стихотворное нравоучение (сургаал) «Законы существования мира: природа органического и материального» («Orčilonggiyin saba šime yertünčüyin axui yosun»), в котором изложены принципы буддийского вероучения. Главная тема данного нравоучения - жизнь как неразрывная цепь рождений и страданий, от которых можно освободиться, только практикой накопления благих заслуг. Усвоив эти наставления, человек должен прийти к пониманию того, что в пределах сансары все без исключения живые существа, подвержены закону причинно-зависимого происхождения.

Таким образом, два ойратских литературных сборника из фонда Национального музея им. АлданМаадыр Республики Тыва является редкими образцами письменного наследия ойратов, в котором отражены присущие старописьменной ойратской литературе художественные, религиозные и философские традиции.

\section{Астрология, гадания, приметы}

В ойратском мире широкое хождение имели астрологические тексты, сборники различных примет, гадательные книги, разнообразные лечебники и рецептники. С помощью таких сборников магических приемов отгоняли злых духов от человека и скота, распознавали коварные и злые намерения людей, вычисляли благоприятные дни для хозяйственных дел и т. д. (Бадмаев, 2014). Из 505 экземпляров ойратской коллекции Института восточных рукописей РАН 114 текстов (многие из которых неполные), тематически отнесены исследователями к разделу «Астрология.Гадания.Приметы». В них представлены различные астрологические сочинения, предсказания о счастливых и несчастливых днях, отрывки из гадательных книг и т. д. (Яхонтова, 2014: 18-20).

K такому виду гадательно-астрологической литературы относятся две последние рукописи из ойратской коллекции НМ РТ. Один из текстов под шифром М-657 «Предсказания по крику сороки» 


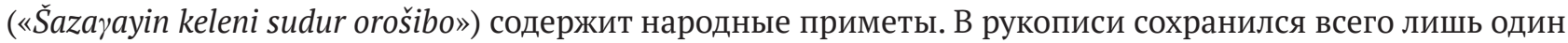
лист.

Рукописные записи всевозможных примет-предсказаний по крикам и полету птиц, лаю собак, внутренним органам животных имели широкое распространение. Иногда такие сборники имели достаточно объемное содержание. К примеру, текст ойратского сборника «Приметы синего барана» («Kükü xucayin ubadis orošibi») состоит из 41 листов среднего размера.

Вторая рукопись под шифром M-884 «Namo Mañzušriyin menggeyin toli» представляет собой сборник примет этой и будущей жизни. Текст написан на восьми листах плотной бумаги желтого цвета. Пагинация отсутствует. На последнем листе текст написан тибетским письмом. В конце тибетского текста приписка на «ясном письме» - «Это справочник (букв. словарь) примет (менге) этой и будущей жизни» («Ene nasun хоyitu nasun хоyoriyin mengge toli ene bui::»).

Сложная астрологическая система лунного монгольского календаря базируется на структуре 5 элементов, каждая из которых имеет определенный цвет (дерево-синий, огонь-красны, земляжелтый, железо-белый, вода-черный) и соотносится с 7 планетами, 28 созвездиями, годами 12 летнего животного цикла, 9 менге (тиб. sme ba) и 8 диаграммами (тиб. spar kha).

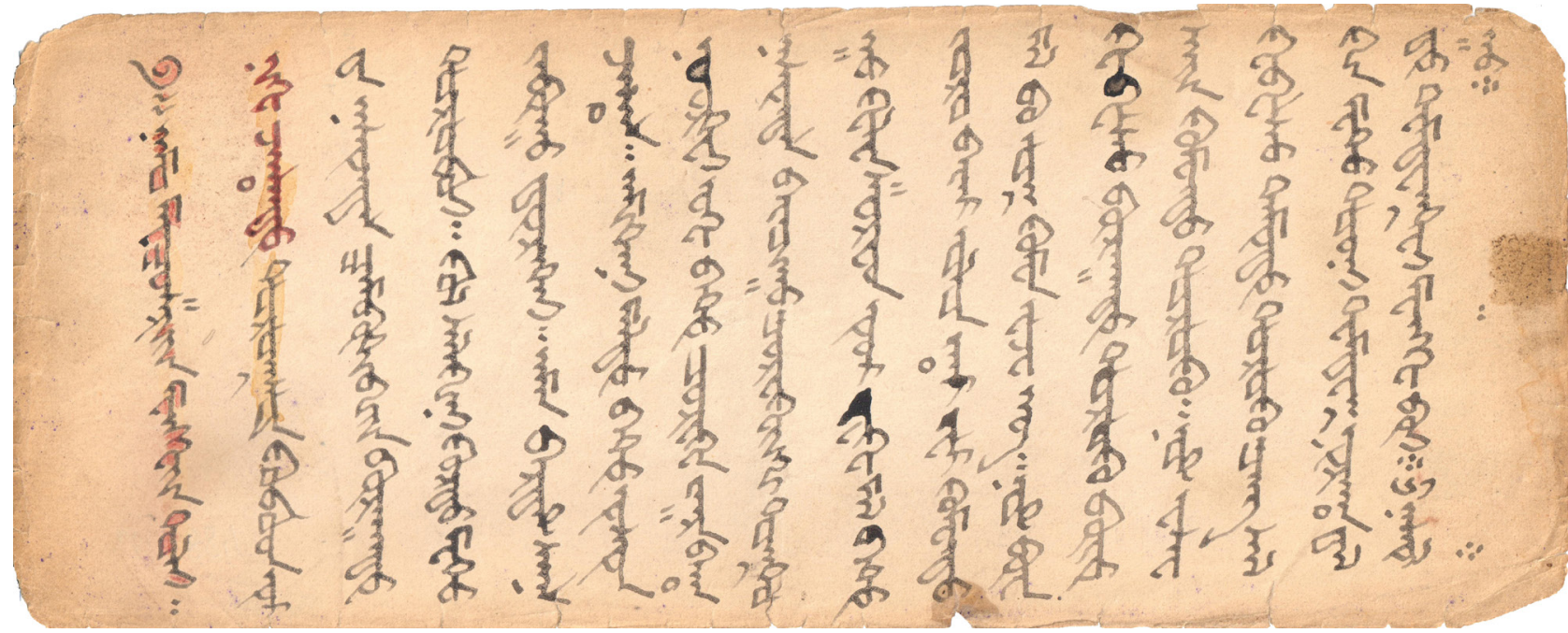

Фото 7. Лист 1а рукописи M-884 «Manzušriyin menggeyin toli». Из фонда Национального музея им. Алдан-Маадыр Республики Тыва.

Photo 7. Page 1a of the manuscript M-884 «Manzušriyin menggeyin toli». From the collections of the Aldan-Maadyr National Museum of the Republic of Tuva.

Текст «Menggeyin toli» представляет собой своеобразный справочник примет, по которым определяется формы прошлого и настоящего рождения, даются рекомендации для обретения благой формы в будущем существовании.

\section{Заключение}

Таким образом, ойратская коллекция НМ РТ свидетельствует о тесной культурно-исторической связи ойратов и тувинцев, которая получила новый импульс в период распространения буддизма на территории Тувы. Вхождение ойратов и тувинцев в пространство буддийской цивилизации с одной стороны способствовало развитию их традиционного мировоззрения, а с другой - раскрывала им путь к освоению великого учения Будды. При этом осмысление духовно-нравственного наследия буддизма синхронно осуществлялось на разных уровнях. Помимо канонических текстов сутр и шастр, в которых излагались философские основы буддийского учения, существовали и доступные для понимания народных масс формы объяснения основ буддийского учения. К таким формам относятся не только притчи о многократных перерождениях и деяниях Будды, а также других персонажей буддийского пантеона, но и многочисленные разъяснения смысла тайных мантр, наставления и поучения, пророчества и предсказания, которые помогали верующим вступить на на путь истинного спасения. 


\section{Благодарности}

Благодарю доктора филологических наук, профессора, директора Национального музея им. АлданМаадыр Республики Тыва К. А. Бичелдея за предоставленную возможность ознакомиться с коллекцией ойратских рукописей.

\section{СПИСОК ЛИТЕРАТУРЫ}

Бадмаев, А. В. (2014) Ойратская рукопись по фармакопее // Мир «ясного письма»: сборник научных статей / отв. ред. Б. А. Бичеев. Элиста: КИГИ РАН. 100 с. С. 88-98.

Бембеев, Е. В., Бичеев, Б. А., Бичелдей, К. А. (2019) Сборник поучений «Ключ разума» из фондов Национального музея Тувы [Электронный ресурс] // Новые исследования Тувы. № 3. URL: https://nit. tuva.asia/nit/article/view/873 (дата обращения: 25.08.2019). DOI: 10.25178/nit.2019.3.14

Билгүүдэй, Г., Отгонбаатар, Р., Цендина А. Д. (2018) Ц. Дамдинсүрэнгийн гэр музейн монгол ном судрын бүртгэл [Каталог монгольских рукописей Дома-музея Ц. Дамдинсурэна]. Улаанбаатар : ШУА ХЗХ. 620 х. (На монг. яз.)

Бичеев, Б.А. (2013) Ойратская версия «Истории Белой Тары» («Повести о Багамай-хатун»). Факсимиле рукописей / исследование, транслитерация, перевод с ойратского, комментарии Б. А. Бичеева. Элиста : КИГИ РАН. 248 с.

Грум-Гржимайло, Г.Е. (1926) Западная Монголия и Урянхайский край. Т. 3. Вып. 1.Антропологический и этнографический очерк этих стран. Составлен Г. Е. Грум-Гржимайло. Ленинград : ГРГО. 412 с.

Зорин, А. В. (2009) Гимны Таре / перевод с тибетского, критический текст, предисловие, приложения А. В. Зорина. М. : Открытый Мир. 272 с.

Лувсанбалдан, Х. (1975) Тод үсэг түүний дурсгалууд [«Ясное письмо» и его памятники]. Улаанбаатар : ШУАХ. 356 х. (На монг. яз.)

Манджиева, Б. Б., Сумба, Р. П. (2019) Рукописный буддийский текст «Стослоговая мантра Ваджрасаттвы» на ойратском языке из Национального музея Тувы [Электронный ресурс] // Новые исследования Тувы. № 3. URL: https://nit.tuva.asia/nit/article/view/874 (дата обращения: 25.08.2019). DOI: 10.25178/nit.2019.3.15

Меняев, Б. В. (2016) Буддийские наказы и пророчества в культуре калмыков и ойратов. Факсимиле рукописей / предисл., введ., библиогр., транслитер., пер., перелож., глосс., прилож. Б. В. Меняева. Элиста : КалмНЦ РАН. 180 с.

Мирзаева, С. В. (2019) Монгольская рукопись «Сутры о восьми светоносных» (монг. Найман гэгээн) из тувинского ар-хива [Электронный ресурс] // Новые исследования Тувы. № 3. URL: https://nit.tuva. asia/nit/article/view/875 (дата обращения: 25.08.2019). DOI: 10.25178/nit.2019.3.16

Мирзаева, С.В., Тувшинтугс, Б. (2019) Монголоязычные версии «Сутры о восьми светоносных» (монг. Найман гэгээн, калм. Нәәмн гегән): об истории изучения и списках в фондохранилищах России // Oriental Studies. № 44 (4). С. 716-727.

Музраева, Д. Н. (2012) Буддийские письменные источники на тибетском и ойратском языках в коллекциях Калмыкии. Элиста: НПП «Джангар». 224 с.

Орлова, К. В. (2002) Описание монгольских рукописей и ксилографов, хранящихся в фондах Калмыкии / Бюллетень Общества востоковедов. Вып. 5. М. : ИВ РАН. 85 с.

Очиров, Н. (1913) Поездка в Александровский и Багацохуровский улусы Астраханских калмыков. Отчет Н. Очирова // Известия Русского комитета для изучения Средней и Восточной Азии. СПб. Сер. II. № 2. C. 78-91.

Сазыкин, А. Г. (1988) Каталог монгольских рукописей и ксилографов Института Востоковедения АН СССР: в 3 т. М. : Издательская фирма «Восточная литература». Т. І. 507 с.

Сазыкин, А. Г. (1992) Собрание монгольских рукописей и ксилографов из фондов Тувинского республиканского краеведческого музея им. 60 богатырей (Кызыл) // Тюркские и монгольские письменные памятники. Текстологические и культуроведческие аспекты исследования : сборник статей / отв. ред. С. Г Кляшторный и Ю. А Петросян. М. : Издательская фирма «Восточная литература». 155 с. С. 45-58. 
Тойм (1976) Монголын уран зохиолын тойм. Хоёрдугаар дэвтэр (XVII-XVIII зууны үе) [Очерк монгольской литературы. Книга вторая (XVII-XVIII вв.)] / редактор Ц. Дамдинсүрэн, Д. Цэнд. Улаанбаатар : ШУАХ. 670 х. (На монг. яз.)

Тунгалаг, Б. (2006) Монгол улсын үндэсний номын сан дахь тод бичгийн судрын гарчиг [Каталог рукописей на «ясном письме», хранящихся в Национальной библиотеке Монголии]. Улаанбаатар : «Тайм принтинг» ХГ. 277 х. (На монг. яз.)

Яхонтова, Н. С. (1992) Ойратский перевод монгольского сочинения «Ключ разума» // Тюркские и монгольские письменные памятники. Текстологические и культуроведческие аспекты исследования : сборник статей / отв. ред. С. Г Кляшторный и Ю. А Петросян. М. : Издательства фирма «Восточная литература». 155 с. С. $137-152$.

Яхонтова, Н. С. (2001) «Ключ разума» (ойратский текст) // Mongolika-V: сборник статей / отв. ред. С. Г. Кляшторный. СПб. : Петербургское востоковедение. 184 с. С. 38-53.

Яхонтова, Н.С. (2014) Ойратские рукописи и ксилографы в собрании Института восточных рукописей РАН // Мир «ясного письма»: сборник научных статей / отв. ред. Б. А. Бичеев. Элиста: КИГИ РАН. 100 с. C. 4-26.

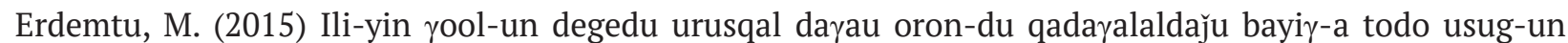
dursqal-tu bičig-un sudulul. 6 [Собрание рукописей на «ясном письме», хранящихся в Илийском округе]. Huh-Hoto : Obor mongrol-un soyol-un keblel-un horyi-a. 387 h. (На монг. яз.)

Gerelmaa, G. (2005) Brief Catalogy of Oirat Manuscripts Kept by Institute of Language and Literature bu Gerelmaa Guruuchin. Ulaanbaatar : XЗХ ШУА. 270 p.

Uspensky, V. (1999) Catalogue of the Mongolian Manuscripts and Xylographs in the St. Petersburg State University Library. Tokyo : Institute for the Study of Languages and Cultures of Asia and Africa. $530 \mathrm{p}$.

Дата поступления: 30.08.2019 2.

\section{REFERENCES}

Badmaev, A. V. (2014) Oiratskaya rukopis' po farmakopee [An Oirat manuscript on pharmacopoeia]. In: Mir «yasnogo pis'ma» [The world of Clear Script]. Collected scientific articles. Ed. by B. A. Bicheev. Elista, Kalmyk Humanities Research Institute of RAS. 100 p. Pp. 88-98. (In Russ.).

Bembeev, E. V., Bicheev, B. A. and Bicheldey, K. A. (2019) Sbornik pouchenii «Klyuch razuma» iz fondov Natsional'nogo muzeya Tuvy ['The Key to Wisdom': A collection of teachings from the funds of the National Museum of Tuva]. The New Research of Tuva, no. 3. URL: https://nit.tuva.asia/nit/article/view/873 (access date: 25.08.2019). DOI: 10.25178/nit.2019.3.14. (In Russ.).

Bilguudey, G. Otgonbaatar, R. and Tsendina, A. (2018) Ts. Damdinsurengiyn ger muzeyn mongol nom sudryn burtgel [Catalog of Mongolian manuscripts of the Memorial House of Damdinsuren]. Ulaanbaatar, Mong. Acad. of Sc. 620 p. (In Mong.).

Bicheev, B. A. (2013) Oiratskaya versiya «Istorii Beloi Tary» («Povesti o Bagamai-khatun») [The Oirat version of 'The Story of White Tara' ('The Tale of Bigamy-Khatun'). Facsimile of manuscripts. Research, translit., translation, comments by B. A. Bicheev. Elista, Kalmyk Humanities Research Institute of RAS. 248 p. (In Russ.).

Grum-Grzhimailo, G. E. (1926) Zapadnaya Mongoliya i Uryanhajskii krai [Western Mongolia and the Uriankhai Contry]. Vol. 3. Part 1. An anthropological and ethnographical sketch of these countries by G. Grum-Grzhimailo. Leningrad, State (Russian) Geographical Society. 412 p. (In Russ.).

Zorin, A. V. (2009) Gimny Tare [Hymns to Tara]. Transl., critical text, preface, annex. by A. V. Zorin. Moscow, Open World Publ. 272 p. (In Russ.).

Luvsanbaldan, Kh. (1975) Tod useg tuunii dursgaluud [Clear Script and its monuments]. Ulaanbaatar, Institute of Language and Literature, Mong. Acad. of Sc. 356 p. (In Mong.).

Mandzhieva, B.B. and Sumba, R.P.(2019) Rukopisny i buddiiskii tekst «Stoslogovaya mantra Vadzhrasattvy» na oiratskom yazy 'ke iz Natsional nogo muzeya Tuvy' [A Buddhist manuscript of 'The hundred-syllable mantra of Vajrasattva' in Oirat language from the National Museum of Tuva]. The New Research of Tuva, no. 3 [online] Available at: https://nit.tuva. asia/nit/article/view/874 (access date: 25.08.2019). DOI: 10.25178/ nit.2019.3.15. (In Russ.). 
Menyaev, B. V. (2016) Buddiiskie nakazy i prorochestva v kul'ture kalmykov i oiratov. Faksimile rukopisei [Buddhist instructions and prophecies in the culture of Kalmyks and Oirats. Facsimile of manuscripts]. Preface, introduction, bibliography, translit., translation, transcr., glossary, appendix by B. V. Menyaev. Elista, Kalmyk Scientific Center of RAS. 180 p. (In Russ.).

Mirzaeva, S. V. (2019) Mongol'skaya rukopis' «Sutry o vos'mi svetonosnykh» (mong. Najman gegeen) iz tuvinskogo arkhiva [A Mongolian manuscript of 'The Sutra on the Eight Luminous of Heaven and Earth' (mong. Naiman gegen) from the Tuvan Archive]. The New Research of Tuva, no. 3 [online] Available at: https:// nit.tuva.asia/nit/article/view/875 (access date: 25.08.2019). DOI: 10.25178/nit.2019.3.16. (In Russ.).

Mirzaeva, S. V. and Tuvshintugs, B. (2019) Mongoloyazychnye versii «Sutry o vos'mi svetonosnyh» (mong. Najman gegeen, kalm. Nəəmn gegən): ob istorii izucheniya i spiskah v fondohranilishchah Rossii [Mongollanguage versions of the Sutra of the eight light-bearers (Mong. Naiman Gegen, Kalm. Naemn gegen): about the history of studying and lists in the Russian storage facilities]. Oriental Studies, no. 44(4), pp. 716-727. (In Russ.)

Muzraeva, D. N. (2012) Buddijskie pis'mennye istochniki na tibetskom i ojratskom yazykah $v$ kollekciyah Kalmykii [Buddhist written sources in Tibetan and Oirat languages in the collections of Kalmykia]. Elista, NPP «Dzhangar. 224 p. (In Russ.)

Orlova, K. V. (2002) Opisanie mongol'skih rukopisej i ksilografov, hranyashchihsya v fondah Kalmykii [Description of Mongolian manuscripts and woodcuts stored in the funds of Kalmykia]. Byulleten' Obshchestva vostokovedov. Iss. 5. Moscow, IV RAN. 85 p. (In Russ.)

Ochirov N. (1913) Poezdka v Aleksandrovskii i Bagatsokhurovskii ulusy astrahanskih kalmykov. Otchet N. Ochirova [A trip to Alexanderovsky and Bagatsokhurovsky Districts of the Astrakhan Kalmyks. A report by N. Ochirov]. Izvestiya Russkogo komiteta dlya izucheniya Srednei i Vostochnoi Azii. St. Petersburg. Is. II. No. 2. Pp. 79-91. (In Russ.).

Sazykin, A. G. (1988) Katalog mongol'skikh rukopisei i ksilografov Instituta Vostokovedeniia AN SSSR [Catalog of Mongolian manuscripts and woodcuts of the Institute of Oriental Studies of the USSR Academy of Sciences]. In 3 vols. Moscow, Nauka. Vol. I. 507 p. (In Russ.).

Sazykin, A. G. (1992) Sobranie mongol'skikh rukopisei i ksilografov iz fondov Tuvinskogo respublikanskogo kraevedcheskogo muzeia im. 60 bogatyrei (Kyzyl) [Catalogue of Mongolian manuscripts and xylographs housed by the Aldan Maadyr Tuvan Republican Local History and Lore Museum (Kyzyl)]. In: Tyurkskie i mongol'skie pis'mennye pamiatniki. Tekstologicheskie i kul'turovedcheskie aspekty issledovaniia [Turkic and Mongolian written monuments. Textual and cultural aspects of the study]. Collected papers. Ed. by S. G Klyashtorny and Y. A. Petrosyan. Moscow, Vostochnaya Literatura. 155 p. Pp. 45-58. (In Russ.).

Toym (1976) Mongolyn uran zohilyn toym [An overview of Mongolian literature]. Second book (XVII-XVIII centuries). Ed. by Ts. Damdinsuren and D. Tsend. Ulaanbaatar, Mong. Acad. of Sc. 670 p. (In Mong.).

Tungalag, B. (2006) Mongol ulsyn ündesnii nomyn san dakh' tod bichgiin sudryn garchig [Catalogue of Clear Script manuscripts stored in the National Library of Mongolia]. Ulaanbaatar, Time Printing. 277 p. (In Mong.).

Yakhontova, N. S. (1992) Oiratskii perevod mongol'skogo sochineniia «Klyuch razuma» [An Oiratsky translation of the Mongol composition 'Key to Wisdom']. In: Tyurkskie i mongol'skie pis'mennye pamiatniki. Tekstologicheskie i kul'turovedcheskie aspekty issledovaniia [Turkic and Mongolian written monuments. Textual and cultural aspects of the study]. Collected papers. Ed. by S. G Klyashtorny and Y. A. Petrosyan. Moscow, Vostochnaia Literatura. 155 p. Pp. 137-152. (In Russ.).

Yakhontova, N. S. (2001) «Klyuch razuma» (oiratskii tekst) ['Key to Wisdom' (Oirat text)]. In: Mongolica-V: collected papers. Ed. by S. G Klyashtorny. St. Petersburg, Peterburgskoe Vostokovedenie. 184 p. Pp. 38-53. (In Russ.).

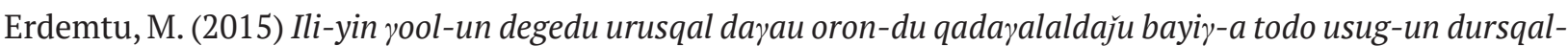
tu bičig-un sudulul 6 [Collection of Clear Script manuscripts stored in Ili District of Xinjiang]. Hohhot, Inner Mongolia Publishing House. 387 p. (In Mong.).

Gerelmaa, G. (2005) Brief Catalog of Oirat Manuscripts Kept by Institute of Language and Literature by Gerelmaa Guruuchin. Ulaanbaatar, Inst. of Lang. and Literature, Mong. Acad. of Sc. 270 p. (In Mong.).

Uspensky, V. (1999) Catalogue of the Mongolian Manuscripts and Xylographs in the St. Petersburg State University Library. Tokyo, Institute for the Study of Languages and Cultures of Asia and Africa. 530 p. 